Journal of Economics and Behavioral Studies

Vol. 7, No. 1, pp. 20-35, February 2015 (ISSN: 2220-6140)

\title{
Antecedents and Consequences of Materialism: An Integrated Theoretical Framework
}

\author{
Helen I. Duh \\ University of Johannesburg (UJ), Auckland Park, Johannesburg, South Africa \\ duhhelen@yahoo.com
}

\begin{abstract}
Materialism has become an integral part of consumers' economic activities and modern day living, with mainly negative consequences reported from materialists' lifestyle. Some of the reported negative consequences of materialism are increasing consumer debt and bankruptcy, shrinking saving, economic crisis and lower levels of life satisfaction and well-being. Consequently, economic psychologists, consumer researchers, sociologists and family psychologists are studying the antecedents of materialism, but there is yet to be an agreement as to how the construct should be defined and on what causes or predicts materialism. Critics of materialism have often seen only negative consequences and blamed marketing activities for the growth of materialism, but substantial academic literature and empirical studies report biological, social, cultural, socio-economic, psychological and even political factors driving materialism. There is therefore a need to develop an integrated and comprehensive theoretical framework, which delineates the various predictors of materialism. There is also the need to highlight the negative, as well as positive consequences of materialism for the interest of retailers, consumer interest groups and policy makers.
\end{abstract}

Keywords: Materialism, consumer socialization, cultural factors, socio-economics, psychological factors

\section{Introduction}

Materialism, the importance placed on material possessions and wealth accumulation, is taking a central place in the lives of many consumers (Hudders \& Pandelaere, 2012), thus raising questions as to what causes materialism (Flouri, 1999) and whether it produces only negative consequences (Richins, 2004). Materialism can play important positive roles in the lives of some people, such as identity builder (Burroughs \& Rindfleisch, 1997), self-esteem booster and satisfier of the need of distinctiveness and belonging (Wong et al., 2011). Shrum et al. (2013, p. 1180) define materialism as "the extent to which individuals attempt to engage in the construction and maintenance of the self through the acquisition and use of products, services and experiences". They therefore see materialism as an identity builder. Brouskeli and Loumakou (2014) found that materialism is a stress buffer. While these researchers see materialism as playing a positive role, most researchers however view materialism as an inescapable and an undesirable aspect of consumer culture (Burroughs \& Rindfleisch, 1997), which leads to a number of negative consequences. The negative consequences include rising and unmanageable consumer debt, depleted savings, consumer bankruptcy, depression, unhappiness, life dissatisfaction (Roberts et al., 2005; Roberts \& Clement, 2007; Tsang et al., 2014) and even the 2008 economic crisis (Kasser, 2008). According to Tsang et al. (2014), materialists are less satisfied with their lives because they have less gratitude. This means that instead of being satisfied with what they have, they focus on what they do not have, thus making them to less likely appreciate positive aspects of their lives.

As a result of the pursuit of materialistic goals in South Africa, for example, the 2012 National Credit Regulator report revealed that consumer debt stood at an alarming level of R1.44 trillion. Consumers are ceasing to save and are increasingly borrowing to enjoy consumption levels which are $30 \%$ higher than their income. Out of about 21 million credit active South African consumers, 10.55 million (about 21\% of South Africa's population) do have impaired records (i.e., not being able to regularly pay their monthly debt instalments (De Waal, 2013). Materialism, Richins (2004) regrets, still persists in individuals and in societies, despite its many negative consumption, emotional, physical and social outcomes. He blames the paradoxical persistence of materialism on the narrow and continuous focus on marketers' contribution to the problem. To better understand materialism and find solutions to its negative outcomes, there is a need to study other myriads of factors driving its growth, so that appropriate measures to curb its growth can be taken (Richins, 
2004). Wong et al. (2011) also recommend that there should be an expanded notion of materialism, which should include its various functions or consequences (i.e., both negative and positive) and its various antecedents. These, they contend, would enhance the understanding of a complex and ambiguous consumer behaviour construct like materialism.

Rationale and Objective of this Study: Even though there are myriads of academic and empirical studies on the various drivers and roles (positive and negative) of materialism, critics have mainly seen negative consequences and blamed marketing activities for the growth of materialism. Heath and Chatzidakis (2012) conducted a semi-structured interview with consumers to assess their perceptions of marketing activities. Their results show that even consumers believe that marketers are the promoters of materialism. Considering this one-sided view of the diver of materialism and the widespread concern about the growth and resultant economic and socio-psychological negative consequences of materialism, Brouskeli \& Loumakou, (2014) stress on the importance of understanding the various drivers of materialistic goals and behaviours. There is also a need for an integrated theoretical framework of what various academic disciplines are reporting about the causes and consequences of materialism (Wong et al., 2011). This study therefore reviews academic essays, journals and books from various secondary data sources to summarise available and updated literature on the consequences (positive and negative) and antecedents of materialism. The study will be of interest to retailers pursuing continuous patronage from materialists, consumer interest groups and policy makers interested in the causes and consequences of materialism.

Definitions and various Conceptualizations of Materialism: The concept of materialism has been viewed from a number of perspectives. Economists for example, view materialism as "an individual's real and desired relationship with economic goods". Economists also see materialism as "the satisfaction one derives from the acquisition and possession of goods, or "the intensity and the manner by which one pursues economic objectives" (Richins \& Rudmin, 1994:218). Sociologists describe materialism as "a personal value that encompasses concern with material things, competitiveness, and emphasis on making profit as opposed to human and societal well-being" (Flouri, 1999:708). The most prominent conceptualizations of materialism are those of consumer researchers like Belk (1985) who sees materialism as a personality trait, Richins \& Dawson's (1992) regard of materialism as a value, Inglehart's (1990) economic and sociological view of materialism. Another important conceptualization of materialism is whether materialism has positive or negative consequences (Claxton \& Murray, 1994, Richins, 2004).

The trait theory postulates that individuals possess innate psychological traits like variety-novelty seeking, sensation seeking, dogmatism, need for distinctiveness and cognition, innovativeness and materialism. These traits may be held in greater or lesser degrees (Schiffman \& Kanuk, 2004:127, 130 \& 150). Of these personality traits, materialism is attracting a lot of consumer researchers' interest, because it is uniquely identified with consumption more than the other personality traits and values (Richins \& Rudmin, 1994). More so, material acquisition and possessions are winning the central place in people's life throughout the world (Ger \& Belk, 1999; Hudders \& Pandelaere, 2012). Belk (1985) and Ger and Belk (1996), who mainly view materialism as a personality-like trait distinguishes materialists as those who regard possessions as essential to their identities and lives and non-materialists as those for whom possessions are secondary. Belk (1985:265) defines materialism as "the importance a consumer attaches to worldly possessions", and as a collection of three personality traits, namely, envy, nongenerosity and possessiveness. Inglehart (1990) employs economic and socio-political hypotheses to define the dynamics of materialistic and post materialistic (opposite of materialists according to Inglehart) societies or cultures. Inglehart (1990:66) uses Maslow's hierarchy of needs to define a materialistic society as that with "a chronic focus on lower order needs for material comfort and physical safety over higher order needs such as self-actualization, belonging, aesthetic satisfaction, and quality of life. He thus considers materialists as people who see lower order needs like economic growth, low crime rates and strong national defence as important social values. This opposes post materialists, who place high importance on higher order social values like intellectual growth, protecting freedom of speech, giving people more say in community, workplace and government decisions and of having impersonal society where ideas matter more than money (Inglehart, 1990:67-68).

Ahuvia and Wong (2002) consider Inglehart's (1990) view of materialism as the most influential (has 2,200 academic citations) theory of materialism. However, Richins and Dawson's (1992) concern about the 
inference of materialism from measures of related constructs creates a weakness of Inglehart's (1990) conceptualization of materialism. Following Rokeach (1973:5) definition of a value as "an enduring belief that a specific mode of conduct or end-state of existence is personally or socially preferable to an opposite or converse end-state of existence", Richins and Dawson (1992:308) define materialism as "a set of centrally held beliefs about the importance of possessions in one's life." Richins and Dawson (1992) thus suggest that materialists value possessions and their acquisition more highly than most other matters and activities in life. Just as a person's value guides his/her judgments, actions, attitudes, and comparisons across specific objects and situations (Rokeach, 1973:18), so too is Richins and Dawson's (1992:307) conceptualization of materialism as "a value that guides people's choices and conduct in a variety of situations, including, but not limited to, consumption arenas". The type and quantity of goods purchased and the allocation of variety of resources, including time, will be for example, influenced by the level of materialism (Richins \& Dawson, 1992). Two common ideas run through Belk's (1985), Inglehart's (1990) and Richins and Dawson's (1992) viewpoints of materialism. These researchers all view materialism as a focus on individualistic goals over collective well-being. They also view materialism as the importance attached to material possessions which result to mostly negative consequences. Wong et al. (2011:2) have expanded the view of materialism to include positive consequences. They define materialism as "the extent to which individuals attempt to engage in the construction and maintenance of the self through consumption".

\section{Consequences of Materialism}

Positive consequences of materialism: Materialism has some positive value for individuals, businesses and society (Richins \& Rudmin, 1994). Materialistic individuals are viewed as people who work hard and for longer hours to earn more money to satisfy their desire for goods, instead of using that time for leisure activities (Richins \& Dawson, 1992). Their high levels of production and consumption can thus increase not only businesses' profits, but can generate capital for research and development. Greater research and development can in turn lead to higher productivity, technological breakthroughs and higher living standards for all (Richins \& Rudmin, 1994; Kasser et al., 2007). Goldberg et al. (2003) found that youths who were materialistic tended to shop more, have more knowledge about products and services and are most responsive to advertising and promotional efforts. They can thus be early adopters, trendsetters, and opinion leaders among their peers.

Tuan (1980:474) states that: "our fragile sense of self needs support and this we get by having and possessing things because, to a large degree, we are what we have". Belk (1988) uses this notion to suggest that possessions help adolescents and adults to manage their identities and to create or maintain a sense of self. Wong et al. (2011) also see materialism as a means of bolstering self-related needs, such as belonging, distinctiveness, efficacy, a meaningful existence and self-esteem. They contend that in an attempt to boost self-esteem, people may chronically pursue materialistic goals. This will be the case because they believe that material acquisitions and possessions may render them more socially attractive, or the pursuit may be a situational response to a self-esteem threat, especially when people feel they are socially excluded. Burroughs and Rindfleisch (1997) found that material objects can be instrumental in reducing the stress children face when parents separate or divorce because the material possessions can restore a sense of stability, permanence, identity, control and a positive self-image. Brouskeli \& Loumakou, (2014) also view materialism as a means of reducing stress. Claxton and Murray (1994) state that human self-concept or identity resides in highly valued objects more than in individuals. Rochberg-Halton (1984:335) thus states that:

"valued material possessions ... act as signs of the self that are essential in their own right for its continued cultivation, and hence the world of meaning that we create for ourselves".

Individuals' material possessions and attachment somehow express their private (for instance, emotions, desires, personal values, memories, impulses etc), public (family relationships, social roles, national, ethnic and religious affiliations) and desired self to others (Webster \& Beatty, 1997). A private value of fun and excitement in life, for example, can be perceived by a person's ownership of a large assortment of recreational equipment. Public values like Christianity and marriage can be expressed or deduced by how much a person values his or her Bible or wedding ring respectively (Richins, 1994). Marketers can use insights into the 
private and public meanings consumers attach to possessions to understand consumption behaviour (Belk, 1988), design promotional messages, target customers and sell their products (Heath \& Chatzidakis, 2012).

The negative consequences of materialism: Materialism has been predominantly associated with negative connotations and consequences (Ryan \& Dziurawiec, 2001). Individuals who pursue material wealth have personal striving for power (desires to impress, control and manipulate others). They thus tend to forego investment in intrinsic values like family, friends, contribution to the community and self-actualization, which are believed to be drivers of life satisfaction or well-being (Kasser \& Ahuvia, 2002, Sheldon \& Krieger, 2014)). Richins (2004) report that due to unreasonably high goals and expectations materialists set for themselves, they tend to evaluate their standard of living unfairly or poorly. This leads to reduced material well-being (an individual's happiness or satisfaction with his or her standard of living), which in turn negatively affect emotional well-being and life satisfaction. Studies in various countries in the U.S., Europe and Asia have confirmed the negative relationship between materialism, life satisfaction and well-being (Baker et al., 2013). Belk (1985) warns that materialism's association with self-centredness, envy, greed, miserliness can lead to some negative outcomes like unhappiness. Kasser and Ahuvia's (2002) study of business students in Singapore revealed that those who had strongly internalized materialistic values also reported higher levels of unhappiness and lower self-actualization. Goldberg et al. (2003) found that young people's heightened focus on materialism in the U.S. led them to have negative attitudes toward school and performed poorly in school. These, Goldberg et al. (2003) suggest, can push them to be sexually promiscuous, drug addicts and some can eventually commit suicides.

Unlike non-materialists who are content with far less in life and can accept low-paying social service work, materialists have insatiable desire for higher-paying professions and higher income. With these attitudes some go to the extent of committing crimes and fraud to increase their wealth. They end up having relatively low levels of well-being, happiness, and are more likely depressed (Roberts et al., 2005). Asserting that people's lesser focus on intrinsic values (e.g. caring for others and the society) is the cause of life dissatisfaction, Sheldon and Krieger (2014) compared the happiness, income and drinking behaviour of 1145 service-focused (intrinsic) lawyers and 1414 materialistic (extrinsic) lawyers. They found that compared to the materialistic lawyers, service lawyers earn far much lower incomes, but they however were happier, have less negative feelings and drank less. Watson (2003) asserts that the numerous wants for consumer goods, travel and recreation can push materialists' savings into the background and cause them to accumulate huge debt. He reports that materialistic attitudes caused U.K. to register household debts of $£ 666$ billion in 1999. U.S. non-mortgage debt stood at \$1.3 trillion in 1998, and Canada's average personal debt in 1998 was greater than average disposable income. Increased number of consumers filed for personal bankruptcy because of the inability to settle their debts in the US (Richins \& Rudmin, 1994; Roberts \& Jones, 2001).

Even in an affluent society, such as Iceland where the per capita GDP in 2007 was $\$ 63,830$, compared to $\$ 45,845$ in the US (Garðarsdóttir \& Dittmar, 2012), one would expect majority of the citizens to be able to adequately sustain themselves from their income. Garðarsdóttir and Dittmar (2012) however reports that because of materialism and unsecured lending, Icelanders on average are living way beyond their means This caused consumer debt to rise to about $255 \%$ of aggregate disposable income in 2008 as compared to $159 \%$ in 2000. In South Africa, it is reported that the amount of debt consumers owed as part of their income was 75.6\% in 2013 (Moneyweb, 2013). Kasser (2008) contends that materialistic values are most probably the drivers of the deregulation of the finance industry, the offer of highly risky bank loans and consumers' desire to take out these loans; all of which led to the 2008 economic crisis. When citizens are materialistic, he continues, consumers consume more and borrow money more. Bank employees make very risky and highly untenable loans to customers. Nations pursue highly competitive forms of capitalism with little governmental regulation, all of which led the 2008 economic crunch. Materialism does not only deplete personal income, it does also have negative consequences on the natural environment because nature's resources are being used at unnecessarily high rates to satisfy the incessant material wants of materialists (Richins \& Rudmin, 1994; Garðarsdóttir \& Dittmar, 2012). Ahuvia and Wong (2002) also report that high levels of material consumption are the driving force behind ecological degradation.

Increasing materialism and desire for Western goods in some Third World countries have reduced the consumption of locally produced goods on which their economy depends, thus increasing unemployment and 
negative balance of payments (Richins \& Rudmin, 1994). Batra et al. (2000) reported that because consumers in developing countries are relatively less affluent, they naturally feel a sense of insecurity and inferiority. To overcome this, they emulate the Western materialistic philosophy by purchasing Western brands they are exposed to through movies and TV channels, Western tourists, their own workers gone overseas, and their travel abroad. Assessing the balance between private and public spending over the last decade, Schor (1998) noted that the support for public goods and services like education, health services taxes; public safety, recreation and culture have been dwindling in support of private spending on material comfort. Given the widespread concerns with materialism, researchers are studying the antecedents of materialism.

\section{Antecedents of Materialism}

Considering that materialism is an ambiguous construct (Flouri, 1999), researchers have used a wide variety of theoretical perspectives to generate ideas of what causes materialism (Larsen et al., 1999). Materialism, according to Muncy and Eastman (1998) does not easily lend itself to test of causality but as Flouri (1999), Larsen et al. (1999) and Ger and Belk (1996) recommend, reviewing research on the innate, individual, political, consumer socialization and cultural differences can provide valuable information of how materialistic values are formed or developed.

Innate antecedents of materialism: Larsen et al. (1999) propose that biological factors like gender and age can explain some degree of an individual's tendency to become materialistic.

Gender differences in materialism: Females' greater interest in people and males' interest in objects (Larsen et al., 1999) are giving researchers the idea that males might be more materialistic than females. Browne and Kaldenberg (1997), Eastman et al. (1997), Flouri (2004) and Segal and Podoshen (2013) all support the suggestion by their findings that men are more materialistic than women. According to Roberts and Clement (2007), men equate material possessions to happiness than women. When women are however uncertain about their self-concept, they score higher than men in materialism (Noguti \& Bokeyar, 2014).

Age differences in materialism: Developmental psychologists like Piaget (1973) hold the view that the tendency to be materialistic is a developmental process. Considering that children may be more possessive, envious and nongenerous, Larsen et al. (1999) propose that children are likely to be more materialistic than young adults, and young adults more materialistic that older adults. Churchill and Moschis (1979) also see a positive relationship between an adolescent's age and the strength of materialism. Based on sociological theory, Moschis (1987) explains that as adolescents mature, they strive for independence from parents. They thus spend more time interacting with peers or increase their frequency of television viewing, all of which affect the development of materialistic values. Flouri's (2004) findings also show that there is a positive relationship between age and materialism. Contrary to the views that materialism increases with age, Brouskeli and Loumakou (2014) found that materialism decreases with age. Chaplin and John, 2007) also report that materialism declines from early (12-13 years) to late adolescence (16-18 years). Self-esteem, Chaplin and John (2007) argue, drops dramatically around ages 12-13 and then rebounds with the approach of late adolescence. Thus, a self-esteem change over different age groups is what accounts for materialism and not the age differences per se. Chaplin and John (2007) highlight that, socialization agents like peer group, media and family often thought to affect the development of materialistic values in young people yield their influence indirectly through their impact on self-esteem.

Birth order differences in materialism: Reviewing research on the privileges that firstborn children have over later-borns, Churchill and Moschis (1979) propose that the exclusive affection of parents which firstborn children receive may cause them to model after parental or family consumption values and orientations. This orientation, they claim, is usually an economic or rational consumption orientation. Conversely, later-borns more frequently interact with peers who may socialize them toward a social or materialistic orientation. According to Rink (2010), firstborn are more likely to become materialistic because parents tend to be overprotective of their firstborn and in the process, frustrate firstborn's need for independence. Growing up being dependent and lacking a point of reference, firstborns may become anxious, affiliate with peers, and for self-evaluation, they may use the process of social comparisons, all of which are drivers of materialism. 
Consumer socialization into materialism: While biological factors play a role in predicting materialism, views on the development of materialistic values especially in young adults are according to BenmoyalBouzaglo and Moschis (2010) mainly based on socialization. Sources of socialization may be peers, mass media and the family. Ward (1974:2) defines consumer socialization as "processes by which young people acquire skills, knowledge, and attitudes relevant to their functioning as consumers in the marketplace". Ward (1974) reiterate that through consumer socialization, consumers acquire consumption-relevant skills (like budgeting, pricing), knowledge (of brand attributes and shopping outlets), and attitudes (toward products, brands, and sales people) that are necessary for direct and indirect (purchase through motivators) enactment of the consumer role. Various studies have gained the understanding of how consumption skills, norms, attitudes and knowledge are acquired by focusing on the role of television (Churchill \& Moschis, 1979), peer groups (Achenreiner, 1997), and family influence and communication (Grossbart et al., 1991; Moschis, 1985) as socialization agents. How these socialization agents affect the development of materialistic values are discussed next.

Television viewing and materialism: The mass media like television is reported to be playing an important role in socializing consumers into materialism. Churchill and Moschis (1979) and Pollay (1986) found that TV viewing and advertising reinforces materialistic ideals, especially in young people. Roberts (1998) assesses that teenagers on average spend about 21 hours per week watching TV. The TV portrays affluence, luxurious settings, clothing styles and fashionable brands as desirable and a way of life. The disparity between the appearances, surroundings and possessions shown on TVs, and the viewers' actual state can create a sense of deprivation and a desire to compensate with material acquisition and possessions (Roberts, 1998). According to Moschis (2007), young people's duration and frequency of exposure to consumption-rich portrayals through TV shows and characters may affect the strength of their orientations toward materialism.

Television viewing can also foster the development of materialistic values through TV advertisements' consistent conveyances of messages that project products as solutions to problems. Some advertisements persuade viewers to think that self-worth can be gained from possessions (Goldberg et al., 2003; Roberts, 1998). Advertising has thus received more attention and criticism for being the most potential cause or promoter of materialism. Considering that young people and the poor watch more TV than other age and income group respectively, Larsen et al. (1999) propose that young people and the poor are likely to be more materialistic. In the U.S. for example, Goldberg et al. (2003) assess that massive media advertisement, promotion, public relations and packaging targeted at adolescents do not only aim at capturing their dollars, but are driving them to be preoccupied with materialism. Concerned about the rising levels of materialism among adolescence in the U.K., consumer activists led a "Leave Our Kids Alone" petition in 2013. This was aimed at pushing the U.K. government to ban advertising to children under the age of 11 years (Leave Our Kids Alone, 2013).

Peer influence and materialism: John (1999) and Moschis (1987) consider peers as another source that provides information and role models for emulation, especially among young people. Young people learn materialistic attitudes from peers (Duh et al., 2014). The degree of consumer susceptibility to peer influence which Achenreiner (1997:84) describe as "the predisposition to identify with or enhance one's image in the opinion of peers through the acquisition and use of products and brands", will however depend on the consumer's self-confidence, self-monitoring and frequency of communication with peers regarding consumption matters. People who lack self-confidence and have low self-esteem are more likely to be susceptible to peer influence and as a result, they may adopt materialistic values (Achenreiner, 1997). High self-monitors (individuals with greater sensitivity to notice and modify one's behaviour from external cues) are more susceptible to peer influence (Achenreiner, 1997:84) and more likely to be materialistic (Browne \& Kaldenberg, 1997). According to Chaplin and John (2010) peer and parents are important influence on materialism, especially among adolescents through the degree to which they boost self-esteem by the emotional psychological support provided. To Moschis (1985:898), "it is the family context of interpersonal communication that is believed to have the greatest influence in consumer socialization into materialism".

The family as a socialization agent and cause of materialism: Research on the role of the family in consumer socialization have focused on the processes through which young people acquire skills, values, attitudes, and behaviours from their parents, the role of family communication processes (Benmoyal- 
Bouzaglo \& Moschis, 2010; Moschis, 1985) and how the frequency of shopping with children (co-shopping) affect consumption orientations such as materialism Grossbart et al., 1991). While adolescents and teenagers may more often look to their friends for models of acceptable consumption behaviour, preadolescents acquire their consumption values, norms and attitudes through the observation of their parents and siblings. The consumption orientation adolescents eventually adopt from their families depends on the frequency of coshopping, communication with parents about consumption matters (Churchill \& Moschis, 1979) and the consumption orientation of parents themselves (Goldberg et al., 2003). According to Churchill and Moschis' (1979) report, adolescents who frequently communicate with parents about consumption matters are more likely to adopt a rational or economic consumption orientation. However, if parents are materialistic, their children will tend to be materialistic as well (Goldberg et al., 2003). There is much evidence suggesting that certain parental styles promote or deter the development of a person's materialistic values. According to Ryan and Deci's (2000) self-determination theory, some environments are more successful in satisfying individuals' psychological needs and giving them the opportunity to grow, while some are not. Kasser et al. (2002) use this view to propose that people's psychological needs of autonomy and relatedness are well satisfied when the environments they grew up in provided love, encouragement, and acceptance of their unique perspective and desires in life. People whose need of autonomy was satisfied, grow up holding intrinsic values like self-expression, self-actualization, intimate relationship with others and community support more important than extrinsic values like financial success and materialism.

Children whose parents' communication style was cold, controlling, rejecting and opportunities were not given for intimacy and self-expression as opposed to those whose parental style was warm, and democratic, grow up attaching importance on extrinsic values like materialism (Kasser et al., 2002). Kasser et al.'s (1995) empirical work on this proposal show that teenagers growing up with warm, democratic moms were more focused on self-acceptance, affiliation and community feeling values. Conversely, those with cold, controlling mothers had higher likelihood to endorse financial success values. Children in Cohen and Cohen's (1996) study whose parents were more punishing and possessive scored higher in materialistic values. Cohen and Cohen (1996) assessed the differences in materialism between children from lower-income and those from upper-income families. They found that the lower-income children would more likely concern themselves with materialistic values based on emotional insecurity and a desire to impress others. Chaplin et al. (2014) confirm this Cohen and Cohen's (1996) finding.

Cross-cultural differences in materialism: Consumer research studies commonly view materialism as an individual phenomenon, but there are differences in materialism within and across various cultures (Clarke \& Micken, 2002; Webster \& Beatty, 1997). Larsen et al. (1999) describe a materialistic culture or nation as one in which most people value material possessions highly. Turkish consumers for example, were found to be more materialistic than American and European consumers, because of their cultural history of valuing material prosperity (Ger \& Belk, 1990). A number of variables have been used to explain why there are crosscultural differences in materialism. Researchers report that cross-cultural differences in materialism can be attributed to a nation's political ideology, religious beliefs and affiliations, level and content of advertising (Larsen et al., 1999), cultural values of either individualism or collectivism (Kitayama \& Markus, 1992), and socio-economic inequality (Roth, 1995a). Politically, Larsen et al. (1999) suggest that people in nations that relatively value economic freedom or embrace free-market economic system over a redistributionist ideology, are more likely to be materialistic. This happens because there are limited or no restriction on quantity and quality of properties and material objects people can own. Larsen et al. (1999) are as well of the opinion that Protestant nations are likely to be more materialistic than Catholic nations because protestants tend to view material blessings as a sign of God's grace, to the extent that they diligently sought after material wealth. Catholic nations, on the other hand, have traditionally honoured a frugal lifestyle of monastery as a spiritual ideal.

People in countries that allow high levels of advertising, especially the transformational (involving symbols of social status, wealth and conspicuous consumption) advertisements, are according to Larsen et al. (1999) likely to be more materialistic. Eastern Asian consumers' attraction to high image, high status advertisements and products like Chanel, Gucci, Louis Vuitton, have raised the suspicion that they may be more materialistic than their Western counterparts (Wong \& Ahuvia, 1995). This is especially so because there is a positive relationship between status consumption and materialism (Eastman et al., 1997). Webster and Beatty (1997) 
conducted an empirical study that compared the level of materialism between Thai and American consumers. Their findings reveal that Thai consumers are more materialistic than American consumers and distinctly place more importance on the success dimension of materialism. While the American consumers place more importance on the possessions that reflect the private self, the Thai counterparts place more importance on possessions that reflected the public self. This may be so, because Thailand embraces the cultural value of collectivism (Komin, 1991) as opposed to Americans who are individualists (Kitayama \& Markus, 1992). Burroughs and Rindfleisch (2002) however report that there is a negative relationship between materialism and collective-oriented values. They also see a positive relationship between individualism and materialism. This raises questions about Webster and Beatty's (1997) claim of Thais being more materialistic, when they are collectivists. Thailand, according to Ger and Belk's (1996) cross-cultural study of twelve nations, was one of the countries labelled as least materialistic. Eastman et al.'s (1997) and Clarke and Micken's (2002) crosscultural comparison of materialism consistently found Mexicans least materialistic because they embrace a collectivist (followers of social norms, form relationships, make decisions, and initiate behaviours dependent of others) cultural values as opposed to individualistic (people's tendency to value personal and individual time, freedom, experiences and to make decisions independent of others - Roth 1995a:165) values.

Socio-economic Growth and Materialism: Socio-economically, regions have been assessed in terms of its "modernity," which Roth (1995a:168) defines as "a measure of the institutions and organizations that provide life experiences for members of a society". One aspect of modernity that relates to consumption is disposable income. Disposable income indicates the amount of resources consumers allocate to goods and services (Roth, 1995a). Common view holds that when resources are limited, consumers use goods and services to satisfy their most basic, functional needs. As resources increase, so does consumer willingness to spend money on products that satisfy more symbolic and sensory needs (Roth 1995a). Contrary to this common view, Ger and Belk (1996:58) found that because of a demonstration effect; less economically developed nations tend to imitate the more extravagant and symbolic consumption of economically developed consumers. The demonstration effect according to Batra et al. (2000) is more prominent when regions become more modern and their exposure to material culture increases. This thus motivate people to both desire the goods they see being consumed in Western cultures and to purchase products that associate them with other cultures and societies. High level of modernity also fosters more individual and self-awareness values, which are associated with needs for self-enhancement, personal fulfilment and materialism (Roth, 1995a).

Ger and Belk's (1996) exploration of materialism in twelve countries found Romanians to be most materialistic, followed by Americans, New Zealand, Ukraine, Germany and Turkey. Sweden was the nation with the lowest score on materialism. An explanation for the high level of materialism in Romania, Ukraine and Turkey was the dramatic and sudden change in these countries economic and political environments. Sudden urbanization or commercialization, Ger and Belk (1996) noted, can increase materialism. Romanians for example, saw a sudden leap from 15 years of severe deprivation of basic items like food, heat, water, electricity and gas to an exposure and influx of Western goods and services after their 1989 revolution. In the same vein, Management Today (2008:45) reports the following about South Africa's rapid growth of a middle class:

"...nowhere else has a new middle class emerged as rapidly, largely as a result of a single, very sudden, comprehensive socio-political economic disruption caused by the absolute termination of a pervasive and categorical system called apartheid".

In most societies, it takes four to five generations for a group to rise from poverty to an affluent middle class, but in South Africa, it took less than 15 years for a considerable proportion of the population to rise to middle class status (Management Today, 2008). Larsen et al. (1999) assert that the more rapidly and recently people's attainment of higher class status, the more materialistic they are likely to become. One thus questions whether a significant proportion of South Africans who have rapidly and recently transited from lower class status to middle class will become materialistic. Sweden, Ger and Belk (1996) compare, scored lowest in materialism because they have an aristocratic tradition along with social democracy and fairly equally distributed income. This raises another question as to whether the massive income inequality in South Africa and questionable social democracy will encourage South Africans to become materialistic. Chang and Arkin (2002) after all, found that perceived anomie (beliefs that society lacks clear guidelines for 
behaviour and reliable sanctions for illegitimate acts) in society may encourage the endorsement of materialistic values because materialism may supply purpose and meaning in life.

Research findings suggest that consumer materialistic desires are stimulated not only by relative socioeconomic deprivation and insecurities (Ger et al., 1993; Inglehart, 1990; Chaplin et al., 2014), but mainly by the psychological problems they create. Whitebeck et al. (1991) for example, investigated the direct and indirect effects of family economic hardship on the self-esteem of adolescents. They found that the family's economic hard times were detrimental to early adolescents' self-esteem not because of the economic situation per se, but because the economic hardship diminished the psychological support these children got from their parents. The next section thus examines the psychological drivers of materialism.

Psychological Predictors of Materialism: Much of contemporary consumer behaviour seems to be geared toward the purchase of goods and services not for economic and utilitarian purposes but for psychological benefits (Dittmar, 2005). Yet, very limited consumer research has been conducted to explain the psychological causes of materialism. This section looks at some psychological predictors of materialism.

Money attitudes and materialism: People grow up having varying values they attach to money. Some people grow up becoming tight, while others may become loose with money. These money attitudes can promote or deter the development of materialistic tendencies (Tatzel, 2003). Yet, limited studies have examined how money attitudes impact on materialism. As an exception, Christopher et al. (2004) Durvasula and Lysonski (2010) assessed the relationship between money attitudes and materialism among US and Chinese students respectively. They commonly found that money attitudes clearly have an impact on materialism, with the power-prestige money attitude dimension having the greatest impact, followed by the anxiety dimension. The Chinese subjects, Durvasula and Lysonski (2010) explain, who saw money as a tool of power had greater tendency to acquire and possess material goods to demonstrate their social power. Anxiety sets in when there is the perception that money in possessions is not enough to achieve their materialistic goal.

Life satisfaction: cause or consequence of materialism: Studies on the psychological correlates of materialism have mainly focused on the psychological consequences rather than the causes. Researchers have consistently proven that there is a negative relationship between materialism and psychological well-being or life satisfaction (Belk, 1985; Kasser \& Ahuvia, 2002; Sheldon \& Krieger, 2014). Kasser and Ahuvia (2002:138) go as far as suggesting that "materialistic ambitions, even when successfully pursued, are relatively empty in terms of potential well-being benefits". Their research findings show that highly materialistic business students in Singapore also reported low self-actualization, increased unhappiness and anxiety. Ryan and Dziurawiec (2001) found in Australia that even adults who scored high in materialism were less satisfied with their 'life as a whole' and with specific life domains such as standard of living and family life (satisfaction with spouse/partner/children) than the less materialistic individuals. Other researchers are questioning whether dissatisfaction in life is the cause of materialism or the result. Those who are dissatisfied in life, Flouri (2004) suggest, may turn to materialistic orientation in an effort to find happiness. According to Sheldon and Krieger (2014), it is rather materialistic orientation that leads to life dissatisfaction.

A materialist, according to Richins and Dawson (1992) is one who seeks for happiness through the acquisition and possessions of material objects. An answer therefore, of the psychological factors, which have robbed materialists of happiness can provide some suggestions of the psychological predictors of materialism. Sharma and Malhotra (2010) suggest that happiness originates from social support, economic and physical well-being and from individual characteristics such personality traits, self-esteem, and a sense of humour. Out of these determinants of happiness, self-esteem has been consistently labelled as a powerful predictor of materialism (Burroughs \& Rindfleisch, 1997; Chaplin \& John, 2007; Moschis, 2007; Richins \& Dawson, 1992). Its definition and ability to predict materialism is discussed next.

Self-esteem, a predictor of materialism: Self-esteem is a person's positive or negative evaluation of his/her self-worth and has been defined as "the disposition to perceive oneself as competent to cope with life challenges and be deserving of happiness" (Adediwura, 2007:213). According to Fournier and Richins (1991) and Richins and Dawson (1992), people with lower feeling of self-worth become materialistic because they 
are caught in an endless cycle of acquiring material goods in hopes of compensating for the feelings of insecurity and searching for happiness. If low self-esteem is a predictor of materialism, Kasser et al. (2004) recommend that experiences that induce feelings of insecurity and low self-esteem should be investigated to get a deeper understanding of how materialistic values develop. Dittmar (2005) uses Wicklund and Gollwitzer's (1982) self-completion theory to explain what causes self-discrepancies or a lower sense of selfworth. Dittmar (2005:836) describe Wicklund and Gollwitzer's (1982) theory of self-completion as the act of judging one's self-worth in terms of competences in some self-identified domains. This process is termed selfdefinition. Self-definition may expose self-discrepancies which Dittmar (2005:836) define, as the disparity between how an individual sees her/himself (actual self) and how s/he would ideally wish to be (ideal self). Individuals who perceive shortcomings in their self-concept or a sense of incompleteness in a self-identified domain are motivated to compensate. One of the strategies that individuals use to compensate for selfdiscrepancies could be the acquisition and usage of material goods that symbolize those aspects of self felt to be lacking (Noguti \& Bokeyar, 2014). Tennis playing beginners, who were committed to the game for example, were found to more likely indulge in branded tennis clothing than expert players to convince themselves and others of their competence. The larger the perceived gap between the ideal self and actual self, the greater the level of materialism (Dittmar, 2005).

Family psychologists like Hill et al. (2001) believe that, disruptive family outcomes such as a decrease in family resources (like food, clothing and emotional support) and stress (in terms of family reorganizations of roles prompted by parental divorce) are aspects that weaken emotional security and self-esteem. Thus, consumer researchers who have modelled family disruption and its effects on materialism have generally speculated that children reared in stressful disrupted families with inadequate family resources become materialistic because these circumstances impair their self-esteem (Burroughs \& Rindfleisch, 1997; Rindfleisch et al., 1997; Roberts et al., 2006; Moschis, 2007). These claims are yet to be empirically proven.

Probing Childhood Family Experiences to Understand Materialism: A New Approach: Moschis (2007) noted that models developed to understand materialism focused on the drivers at a given point in a person's life time, without considering the impact of childhood experiences and circumstances. He views this approach as a shortcoming in consumer research and recommends the use of the life-course approach to study consumer behaviour and consumption orientations such as materialism. The life-course approach employs a multi-theoretical and interdisciplinary (e.g., sociology, history, family and consumer psychology) framework to examine the effects of childhood experiences on later-life behaviour (including behaviours in schools, workplace and in consumption). For the understanding of consumption orientations such as materialism and compulsive buying behaviour, Moschis (2007) proposes the use of three (human capital, stress and socialization) life-course theoretical perspectives. These three life-course theoretical perspectives suggest different socio-psychological processes linking changes in childhood family structure (e.g., from an intact two-parent family to a disrupted single-parent family) and it's accompanying events to changes in consumption orientations. Moschis' (2007) three life-course theoretical perspectives provide various explanations of how early-life family experiences affect later-life consumption orientations.

Considering that the three life-course theoretical perspectives are relatively new paths to understanding consumption orientations, Moschis (2007) recommended their cross-cultural testing for validity. They were thus tested in the US (Baker et al. 2013), Australia (Weaver et al., 2011), France (Benmoyal-Bouzaglo and Moschis, 2010), Brazil (Moschis et al., 2013), Japan (Moschis et al., 2011), Malaysia (Moschis et al., 2009), Thailand (Nguyen et al., 2009) and South Africa (Duh et al., 2014). Some cross-cultural commonalities and differences in how the life-course theoretical perspectives explain materialism were found from these studies. For example, peer communication about consumption during childhood the socialization perspective) was commonly found as a predictor of young adults' materialism in Thailand, Malaysia, Brazil, South Africa and France. Television viewing during childhood (the socialization perspective) was found to have a strong and significant impact on young adults' materialism in Western cultures such as the US and France but not in the Eastern cultures of Japan and Malaysia. Weaver et al. (2011) tested the stress theoretical perspective in Australia and found that perceived stress from disruptive childhood family events positively impacted on materialism at young adulthood. Baker et al. (2013) tested the human capital lifecourse theoretical perspective of materialism in the US, Brazil and France. They found that family resources 
received during childhood plays a mediating role between childhood family disruptions and materialism at young adulthood.

\section{A Proposed theoretical Model of Materialism}

Churchill and Moschis' (1979) conceptual model of adolescents' socialization into the consumption orientations of materialism, social and economic motivation for consumption have mainly examined the television, peers and family antecedents. Flouri's (1999) integrated model of consumer materialism focused on how economic socialization like family money management and maternal values can help predict materialism in adolescents.

Larsen et al. (1999) model of the antecedents and consequences of materialism proposed a number of innate, individual and cultural factors that can cause and result from materialism but did not consider the psychological predictors.

Figure 1: Proposed theoretical model of the antecedents and consequences of materialism

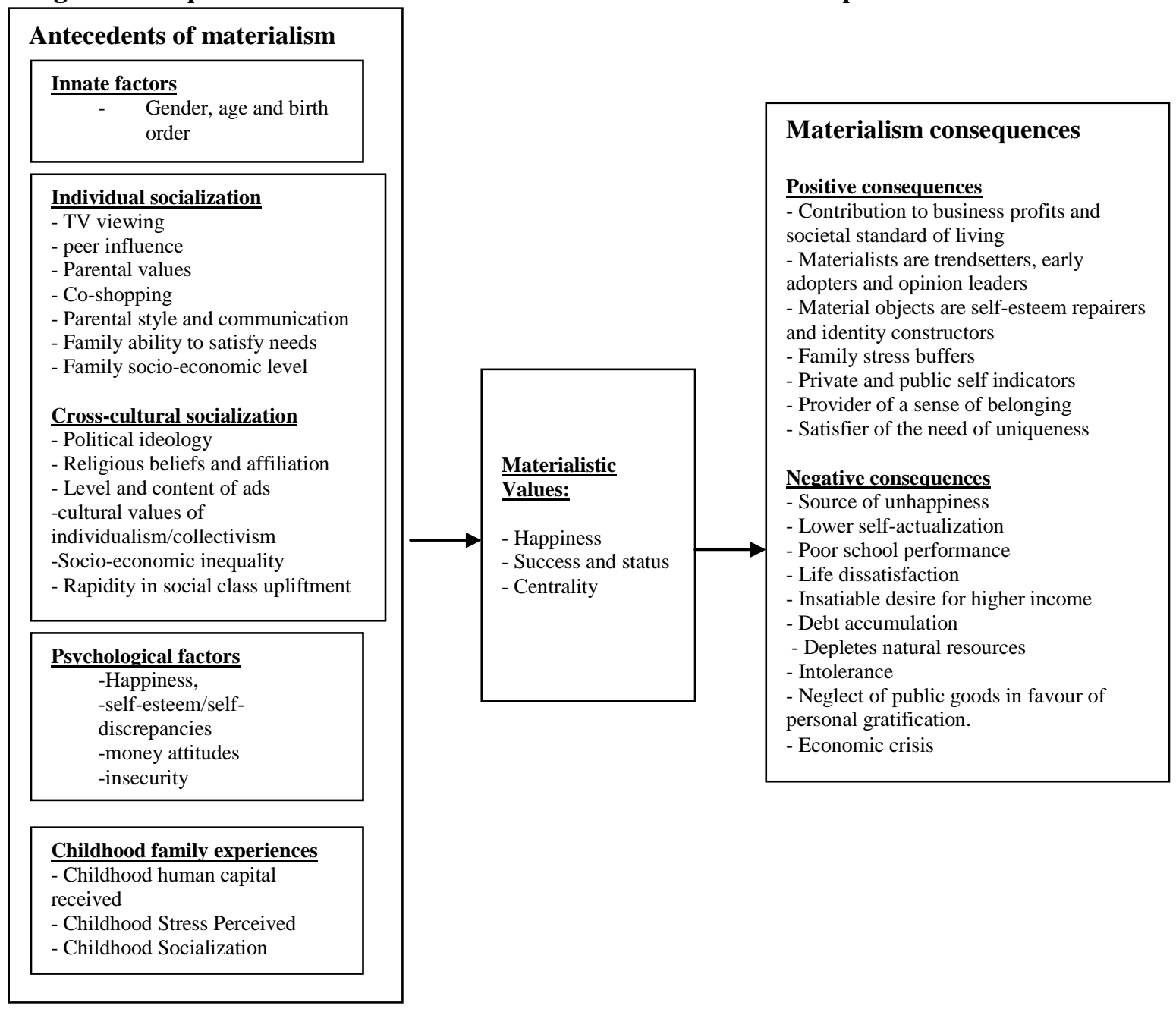

Source: Researcher's summary from overview of literature on materialism

Ger and Belk (1996) mainly provide explanations of how and why some nations are more and less materialistic. Social psychologist (Dittmar, 2005), family psychologist (Hill et al., 2001) and some consumer researchers (Chang \& Arkin, 2002; Richins \& Dawson 1992; Rindfleisch, et al., 1997) agree that low selfesteem or self-discrepancies is a powerful motivator of materialism. Moschis (2007) life-course framework 
provides socio-psychological factors linking childhood family experiences to materialism. From a review of these researchers' literature there is a need to summarize and propose a theoretical model of the innate, individual socialization, cross-cultural, psychological and childhood family experiences' antecedents of materialism. Figure 1 presents the theoretical model, which also highlights the positive and negative consequences of materialism. Figure 1 shows that an understanding of the antecedents and consequences of materialism is embedded in diverse variables or domains of study.

\section{Conclusion}

In this study, a thorough review of secondary academic sources was conducted on the antecedents and consequences (positive and negative) of materialism. It developed a theoretical framework, which provided a summary of the reported antecedents and consequences of materialism. The conceptualization of the theoretical framework is done by carefully scrutinizing journal articles, dissertations and other academic essays in a number of databases to provide a scholarly insight into the concept of materialism. Innate, individual, consumer socialization, cultural, socio-economic, psychological and political system differences were found to be factors driving the development of materialistic values. From all of the models of materialism reviewed, there was limited study on the psychological drivers of materialism. Even though people low and high in materialism may differ in their money attitudes, studies on the impact of money attitudes on materialism was limited. Research is needed to investigate more psychological drivers of materialism and how socio-psychological factors emanating from childhood family experiences affect laterlife materialism.

\section{Reference}

Achenreiner, G. B. (1997). Materialism Values and Susceptibility to Influence in Children. Advances in Consumer Research, 24, 82-88.

Adediwura, A. A. (2007). Religiosity and Perceived Family Support as Correlate of Nigerian University Undergraduates Self-esteem. Ife Psychologia: An International Journal, 15(2), 212-225.

Ahuvia, A. C. \& Wong, N. Y. (2002). Personality and Values Based Materialism: Their Relationship and Origins. Journal of Consumer Psychology, 12 (4), 389-402.

Baker, A., Moschis, G. P., Benmoyal-Bouzaglo, S. \& Pizzutti, C. (2013). How family resources affect materialism and compulsive buying: a cross-country life course perspective. Journal of Cross-Cultural Research, 47(4), 335-362.

Baker, A. M., Moschis, G. P., Ong, F. S. \& Pattanapanyasat, R. (2013). Materialism and Life Satisfaction: The Role of Stress and Religiosity. Journal of Consumers Affairs, 47(3), 548-563.

Batra, R., Ramaswamy, V., Alden, D. L., Steenkamp, J. E. M. \& Ramachander, S. (2000). Effects of Brand Local and Nonlocal Origin on Consumer Attitudes in Developing Countries. Journal of Consumer Psychology, 9(2), 83-95.

Belk, R. W. (1985). Materialism: Trait Aspects of Living in a Material World. Journal of Consumer Research, 12, 265-280.

Belk, R. W. (1988). Possessions and the Extended Self. Journal of Consumer Research, 15(2), 139-168.

Brouskeli, V. \& Loumakou, M. (2014). Materialism, Stress and Health Behaviors among Future Educators. Journal of Education and Training Studies, 2(2), 145-150.

Benmoyal-Bouzaglo, S. \& Moschis, G. P. (2010). Effects of Family Structure and Socialization on Materialism: A life Course Study in France. Journal of Marketing Theory and Practice, 18(1), 55-71.

Browne, B. A. \& Kaldenberg, D. O. (1997). Conceptualizing self-monitoring: links to materialism and product involvement, Journal of Consumer Marketing, 14(1), 31-44.

Burroughs, J. E. \& Rindfleisch, A. (1997). Materialism as a Coping Mechanism: An Inquiry into Family Disruption. Advances in Consumer Research, 24, 89-97.

Burroughs, J. E. \& Rindfleisch, A. (2002). Materialism and Well-being: A conflicting Values Perspective. Journal of Consumer Research, 29, 348-370.

Chang, L. \& Arkin, R. M. (2002). Materialism as an Attempt to Cope with Uncertainty. Psychology and Marketing, 19(5), 389-406.

Chaplin, L. N., Hill, R. P. \& John, D. R. (2014). Poverty and Materialism: A Look at Impoverished Versus Affluent Children. Journal of Public Policy \& Marketing, 33(1), 78-92. 
Chaplin, L. N. \& John, R. D. (2007). Growing up in a Material World: Age Differences in Materialism in Children and Adolescents. Journal of Consumer Research, 34, 000.

Christopher, A. N., Marek, P. \& Carroll, S. M. (2004). Materialism and Attitudes toward Money: An Exploratory Investigation. Individual Differences Research, 2(2), 109-117.

Churchhill, G. A. \& Moschis, G. P. (1979). Television and Interpersonal Influences on Adolescent Consumer Learning. Journal of Consumer Research, 6, 23- 34.

Clarke, I. C. \& Micken K. S. (2002). An exploratory Cross-cultural analysis of the values of materialism. Journal of International Consumer Marketing, 14, 65-89.

Claxton, R. P. \& Murray, J. B. (1994). Object-subject interchange ability: a symbolic interactionist model of materialism. Advances in Consumer Research, 21, 422-426.

Cohen, P. \& Cohen, J. (1996). Life values and adolescent mental health, Mahwah, NJ: Lawrence Erlbaun.

Csikszentmihalyi, M. \& Rochberg-Halton, E. (1981). The meaning of things: Domestic Symbols and the Self, Cambridge: Cambridge University Press.

De Waal, M. (2013). South Africans are sinking under debt - and the credit amendment bill won't pull us out, Daily Maverick, 04 June, available at: http://www.dailymaverick.co.za/article/2013-06-04-southafricans-are-sinking-under-debt-and-the-credit-amendment-bill-wont-pull-us-out/\#.UiLTFWucH_Q (accessed 31 August 2013).

Dittmar, H. (2005). A New Look at Compulsive Buying: Self-discrepancies and Materialistic Values as Predictors of Compulsive Buying Tendency. Journal of Social and Clinical Psychology, 24(6), 832859.

Duh, H. I., Benmoyal-Bouzaglo, S., Moschis, G. P. \& Smaoui, L. (2014). Examination of Young Adults' Materialism in France and South Africa using two Life-course Theoretical Perspectives, Journal of Family and Economic Issues. [Available online] http://link.springer.com/article/10.1007/s10834014-9400-9

Durvasula, S. \& Lysonski, S. (2010). Money, money, money - how do attitudes toward money impact vanity and materialism? - The case of young Chinese consumers. Journal of Consumer Marketing, 27(2), 169-179.

Eastman, J. K., Fredenberger, B., Campbell, D. \& Calvert, S. (1997). The relationship between status consumption and materialism: A cross-cultural comparison of Chinese, Mexican, and American Students. Journal of Marketing Theory and Practice, 5(1), 52-66.

Flouri, E. (1999). An integrated model of consumer materialism: Can economic socialization and maternal values predict materialistic attitudes in adolescents? Journal of Socio-Economics, 28, 707-724.

Flouri, E. (2004). Exploring the relationship between mothers' and fathers' parenting practices and children's materialist values. Journal of Economic Psychology, 25(6), 743-752.

Fournier, S. \& Richins, M. (1991). Some Theoretical and Popular Notions Concerning Materialism. Journal of Social Behaviour and Personality, 6, 403-414.

Garðarsdóttir, R. B. \& Dittmar, H. (2012). The relationship of materialism to debt and financial well-being: The case of Iceland's perceived prosperity. Journal of Economic Psychology, 33, 471-481.

Ger, G. \& Belk, R. W. (1990). Measuring and comparing materialism cross-culturally. Advances in Consumer Research, 17, 186-192.

Ger, G. \& Belk, R. W. (1996). Cross-cultural differences in materialism. Journal of Economic Psychology, 17, 5577.

Ger, G. \& Belk, R. W. (1999). Accounting for Materialism in four Cultures. Journal of Culture, 4(2), 183-204.

Ger, G., Belk, R. W. \& Dana-Nicoletta, L. (1993). The Development of Consumer Desire in Marketizing in Developing Economies: The cases of Romania and Turkey. Advances in Consumer Research, 20, 102107.

Golberg, M. E., Gorn, G. J., Peracchio, L. A. \& Bamossy, G. (2003). Understanding Materialism among Youth. Journal of Consumer Psychology, 13(3), 278-288.

Grossbart, S., Calson, L. \& Wlash, A. (1991). Consumer Socialization and Frequency of Shopping with Children. Journal of Academy of Marketing Science, 19(3), 155-163.

Heath, T. P. \& Chatzidakis, A. (2012). The transformative potential of marketing from the consumers' point of view. Journal of Consumer Behaviour, 11(4), 283-291.

Hill, M. S., Yeung, W. J. J. \& Duncan, G.J. (2001). Childhood family structure and young adult behaviours. Journal of Population Economics, 14, 271-299. 
Hudders, L. \& Pandelaere, M. (2012). The silver lining of Materialism: The impact of luxury consumption on subjective well-being. Journal of Happiness Studies, 13, 411-437.

Iglehart, R. (1990). Culture Shift in Advanced Industrial Society, Princeton, NJ: Princeton University Press.

John, D. R. (1999). Consumer socialization of children: a retrospective look at twenty-five years of research. Journal of Consumer Research, 26, 183-213.

Kasser, T. (2008). Materialistic values and the current economic crisis, Psychologists for Social Responsibility Blog of December 24. Available: http://psysr.wordpress.com/2008/12/24/materialistic-valuesand-the-current-economic-crisis/ (Accessed on July 19, 2014).

Kasser, T., Ryan, R. M., Zax, M. \& Sameroff, A. (1995). The relations of maternal and social environments to late adolescents' materialistic and prosocial values. Developmental Psychology, 31, 907-914.

Kasser, T. \& Ahuvia, A. C. (2002). Materialism values and well-being in business students. European Journal of Social Psychology, 33(1), 137-146.

Kasser, T., Cohn, S., Kanner, A. D. \& Ryan, R. M. (2007). Some costs of American corporate capitalism: A psychological exploration of value and goal conflicts. Psychological Inquiry, 18(1), 1-22.

Kasser, T., Koestner, R. \& Lekes, N. (2002). Early Family Experiences and adult values: A 26-year prospective longitudinal study. Personality and Social Psychological Bulletin, 28, 826-835.

Kasser, T., Richard, M. R., Charles, E. C. \& Kennon, M. S. (2004). Materialistic Values: Their Causes and Consequences, in Psychology and Consumer Culture, ed. Tim Kasser and Allen D. Kanner, Washington, DC: American Psychological Association, 11-28.

Kitayama, S. \& Markus, H. R. (1992). Construal of the self as cultural frame: Implication for internationalizing psychology, paper presented at the symposium on internationalization and higher education, University of Michigan, Ann Arbor, MI Draft (April).

Komin, S. (1991). Psychology of the Thai People: Values and Behavioural Patterns, Bangkok: Research Centre, National Institute of Development Administration (NIDA).

Larsen, V., Sirgy, J. M. \& Wright, N. D. (1999). Materialism: The Construct, Measures, Antecedents and Consequences. Academy of Marketing Studies Journal, 3(2), 78-110.

Leave Our Kids Alone. (2013). We Want an Immediate End to All Advertising Aimed at Children Under 11, petition, (accessed November 04, 2014), [available at http://www.change.org/en$\mathrm{GB} /$ petitions/the-uk-government-we-want-an-immediate-endto-all-advertising-aimed-at-childrenunder-11].

Management Today. (2008). BLACK DIAMONDS, the new South African Middle class, May, 43-47.

Moneyweb, (2013). No end to debt troubles, consumers need to cut back, available at: http://www.moneyweb.co.za/moneyweb-financial/no-end-to-debt-troubles (accessed: 19 July 2014)

Moschis, G. P. (1985). The Role of Family Communication in Consumer Socialization of Children and Adolescents. Journal of Consumer Research, 11, 898- 913.

Moschis, G. P. (1987). Life course perspective on consumer behaviour. Journal of Academy of Marketing Sciences, 35, 295-307.

Moschis, G. P. (2007). Life course perspectives on consumer behaviour. Journal of the Academy of Marketing Science, 35, 295-307.

Moschis, G. P., Hosie, P. \& Vel, P. (2009). Effects of family structure and socialization on materialism: Life course study in Malaysia. Journal of Business and Behavioural Sciences, 12(1), 166-181.

Moschis, G. P., Mathur, A., Kwaiffat, C. \& Pizzutti, C. (2013). Effects of Family Structure on Materialism and Compulsive Consumption: A Life Course Study in Brazil. Journal of Research for Consumers, 23, 6696.

Moschis, G. P., Ong, F. S., Mathur, A., Yamashita, T. \& Benmoyal-Bouzaglo, S. (2011). Socialization influences on materialism: across-cultural life-course approach. Journal of Asian Business Studies, 5(2), 124-44.

Muncy, J. A. \& Eastman, J. K. (1998). Materialism and consumer ethics: an exploratory study. Journal of Business Ethics, 17, 137-145.

Nguyen, H. V., Moschis, G. P. \& Shannon, R. (2009). Effects of family structure and socialization on materialism: a life course study in Thailand. International Journal of Consumer Studies, 33, 486-95.

Noguti, V. \& Bokeyar, A. L. (2014). Who am I? The relationship between self-concept uncertainty and materialism. International Journal of Psychology, 49(5), 323-333.

Piaget, J. (1973). The Child and Reality, New York: Penguin Book. 
Pollay, R. W. (1986). The Distorted Mirror: Reflections on the Unintended Consequences of Advertising. Journal of Marketing, 3, 18-36.

Richins, M. L. (1994). Special Possessions and the Expression of Material Values. Journal of Consumer Research, 21, 522-533.

Richins, M. L. (2004). The Positive and Negative Consequences of Materialism: What Are They and When Do They Occur? Advances in Consumer Research, 31, 232-235.

Richins, M. L. \& Dawson, S. (1992). A Consumer Values Orientation for Materialism and its Measurement: Scale Development and Validation. Journal of Consumer Research, 19, 303-316.

Richins, M. L. \& Rudmin, F. W. (1994). Materialism and economic psychology. Journal of Economic Psychology, $15,217-231$.

Rindfleisch, A., Burroughs, J. E. \& Denton, F. (1997). Family structure, materialism and compulsive consumption. Journal of Consumer Research, 23, 312-325.

Rink, D. R. (2010). The impact of birth order upon consumers' decision-making, buying, and post-purchase processes: a conceptualization, Innovative Marketing, 6(4), 71-79.

Roberts, J. A. (1998). Compulsive buying among college students: An investigation of its antecedents, consequences, and implications for public policy. Journal of Consumer Affairs, 32(2), 295-319.

Roberts, J. A. \& Clement, A. (2007). Materialism and Satisfaction with Over-all Quality of Life and Eight Life Domains. Social Indicators Research, 82(1), 79-92.

Roberts, J. A. \& Jones, E. (2001). Money attitudes, credit card use, and compulsive buying among American college students. Journal of Consumer Affairs, 35(2), 213-240.

Roberts, J. A., Manolis, C. \& Tanner, J. Jr. (2006). Adolescent Autonomy and the Impact of Family Structure on Materialism and Compulsive Buying. Journal of Marketing Theory and Practice, 14(4), 301-314

Roberts, J. A., Tanner, J. Jr. \& Manolis, C. (2005). Materialism and the Family Structure-Stress Relation. Journal of Consumer Psychology, 15(2), 183-190.

Rochberg-Halton, E. (1984). Object Relations, Role Models, and Cultivation of the Self. Environment and Behaviour, 16(3), 335-368.

Rokeach, M. (1973). The nature of Human values, New York: Free Press.

Roth, M. S. (1995a). The Effects of Culture and Socioeconomics on the Performance of Global Brand Image Strategies. Journal of Marketing Research, 32(2), 163-176.

Ryan, L. \& Dziurawiec, S. (2001). Materialism and its Relationship to Life Satisfaction. Social Indicators Research, 55, 185-197.

Ryan, R. \& Deci, E. (2000). Self-determination theory and facilitation of intrinsic motivation, social development, and well-being. American Psychologist, 55, 68-78.

Schiffman, L. G. \& Kanuk, L. L. (2004). Consumer Behaviour, $8^{\text {th }}$ edn., Pearson Prentice-Hall. Pearson Education International.

Schor, J. B. (1998). The overspent American: Upscaling, downshifting and the new consumer, New York: Basic Books.

Segal, B. \& Podoshen, J. S. (2013). An examination of materialism, conspicuous consumption and gender differences. International Journal of Consumer Studies, 37(2), 189-198

Sharma, A. \& Malhotra, D. (2010). Social-Psychological Correlates of Happiness in Adolescents. European Journal of Social Sciences, 12(4), 651-662.

Sheldon, K. M. \& Lawrence Krieger, S. (2014). Service job lawyers are happier than money job lawyers, despite their lower income. The Journal of Positive Psychology, 9(3), 219-226

Shrum, L. J., Wong, N., Arif, F., Chugani, S. K., Gunz, A., Lowrey, T. M., Nairn, A., Pandelaere, M., Ross, S.M., Ruvio, A., Scott, K. \& Sundie, J. (2013). Reconceptualizing materialism as identity goal pursuits: Functions, processes, and consequences. Journal of Business Research, 66, 1179-1185.

Tsang, J, Carpenter, T. P., Roberts, J. A., Michael B. Frisch, M. B. \& Carlisle, R. D. (2014). Why are materialists less happy? The role of gratitude and need satisfaction in the relationship between materialism and life satisfaction. Personality and Individual Differences, 64, 62-66.

Tuan, Y. (1980). The Significance of the Artifact. Geographical Review, 70(4), 462-472.

Ward, S. (1974). Consumer Socialization. Journal of Consumer Research, 1, 1-14.

Watson, J. J. (2003). The relationship of materialism to spending tendencies, saving, and debt. Journal of Economic Psychology, 24, 723-739.

Weaver, T., Moschis, G. P. \& Davis, T. (2011). Antecedents of materialism and compulsive consumption: A life course study in Australia. Journal of Australasia Marketing, 19(44), 247-256. 
Webster, C. \& Beatty, R. C. (1997). Nationality, Materialism, and Possessions Importance. Advances in Consumer Research, 24, 204-210.

Whitbeck, L. B., Simons, R. L., Conger, R. D., Lorenz, F. O., Huck, S. M. \& Elder, G. H. Jr. (1991). Family economic hardship, parental support, and adolescent self-esteem. Social Psychology Quarterly, 54(6), 353-363.

Wong, N. Y. \& Ahuvia, A. (1995). Self-Concepts and Materialism: A cross-cultural approach. American Marketing Association, 2, 112-119.

Wong, N., Shrum, L. J., Arif, F., Chugani, S., Gunz, A., Lowrey, T. M., Nairn, A., Pandelaere, M., Ross, S. M., Ruvio, A., Scott, K. \& Sundie, J. (2011). Rethinking Materialism: A Process View and Some Transformative Consumer Research Implications. Journal of Research for Consumers, 19, 1-4. 